\title{
Methylmercury inhibits prolactin release in a cell line of pituitary origin
}

\author{
L.A.L. Maués ${ }^{1}$, B.M. Macchi ${ }^{1}$, M.E. Crespo-López ${ }^{2}$, L.E. Nasciutti ${ }^{4}$, D.L.W. Picanço-Diniz ${ }^{3}$, \\ J. Antunes-Rodrigues ${ }^{5}$ and J.L.M. do Nascimento ${ }^{1}$ \\ ${ }^{1}$ Laboratório de Neuroquímica Molecular e Celular, Instituto de Ciências Biológicas, \\ Universidade Federal do Pará, Belém, PA, Brasil \\ ${ }^{2}$ Laboratório de Farmacologia Molecular, Instituto de Ciências Biológicas, Universidade Federal do Pará, Belém, PA, Brasil \\ ${ }^{3}$ Laboratório de Neuroendocrinologia, Instituto de Ciências Biológicas, Universidade Federal do Pará, Belém, PA, Brasil \\ ${ }^{4}$ Laboratório de Interações Celulares, Instituto de Ciências Biomédicas, \\ Universidade Federal do Rio de Janeiro, Rio de Janeiro, RJ, Brasil \\ ${ }^{5}$ Departamento de Fisiologia, Faculdade de Medicina de Ribeirão Preto, Universidade de São Paulo, Ribeirão Preto, SP, Brasil
}

\begin{abstract}
Heavy metals, such as methylmercury, are key environmental pollutants that easily reach human beings by bioaccumulation through the food chain. Several reports have demonstrated that endocrine organs, and especially the pituitary gland, are potential targets for mercury accumulation; however, the effects on the regulation of hormonal release are unclear. It has been suggested that serum prolactin could represent a biomarker of heavy metal exposure. The aim of this study was to evaluate the effect of methylmercury on prolactin release and the role of the nitrergic system using prolactin secretory cells (the mammosomatotroph cell line, GH3B6). Exposure to methylmercury $(0-100 \mu \mathrm{M})$ was cytotoxic in a time- and concentrationdependent manner, with an $\mathrm{LC}_{50}$ higher than described for cells of neuronal origin, suggesting GH3B6 cells have a relative resistance. Methylmercury (at exposures as low as $1 \mu \mathrm{M}$ for $2 \mathrm{~h}$ ) also decreased prolactin release. Interestingly, inhibition of nitric oxide synthase by $\mathrm{N}$-nitro-L-arginine completely prevented the decrease in prolactin release without acute neurotoxic effects of methylmercury. These data indicate that the decrease in prolactin production occurs via activation of the nitrergic system and is an early effect of methylmercury in cells of pituitary origin.
\end{abstract}

Key words: Mercury; Methylmercury; Prolactin; Oxidative stress; Pituitary; Nitric oxide

\section{Introduction}

Heavy metals, such as methylmercury $(\mathrm{MeHg})$, are environmental pollutants that readily affect human beings by bioaccumulation through the food chain (1). Several reports support the idea that the central nervous system represents a major target of mercury $(1,2)$, and endocrine organs may also accumulate high mercury concentrations (3). Studies performed in humans and animal models have demonstrated that individuals exposed to different forms of mercury show a significant mercury concentration in the pituitary gland (4).

The pituitary gland is a critical neuroendocrine organ with a posterior attachment to the hypothalamus. The pituitary anterior lobe (or adenohypophysis) is anatomically different from the hypothalamus and contains a collection of endocrine cells (5). Adenohypophyseal secretory cells include somatotrophs (nearly $50 \%$ ), which produce somatotropin (growth hormone, GH); corticotrophs (15-20\%), which release adrenocorticotropic hormone; gonadotrophs (10-15\%), which synthesize luteinizing hormone and follicle stimulating hormone; thyrotrophs (3-5\%), which release thyroid stimulating hormone; and lactotrophs (10-25\%), which release prolactin (PRL) (5). Disturbances in pituitary physiology result in hypo- or hyper-secretion of these hormones. Although the pituitary gland has already been highlighted as a potential target of mercury accumulation (4), the effects of this metal on the regulation of hormonal release are unclear. Previous studies showed associations (both positive and negative) between serum PRL and mercury exposure (6). This dual effect may be explained by different interactions between mercury species (inorganic and organic) and PRL secretion by the pituitary gland, which is controlled by neurotransmitters such as dopamine. Thus, serum PRL was suggested as a possible biomarker of heavy metal exposure (7); however, the cellular mechanism remains unknown.

PRL is a single chain protein with 199 amino acids and three disulfide bridges (sharing strong structural homology

Correspondence: J.L.M. do Nascimento: <jlmn@ufpa.br>.

Received June 3, 2014. Accepted January 15, 2015. First published online June 23, 2015. 
with $\mathrm{GH}$ ) (8). The major role of PRL is stimulating breast development and milk production. However, more than 300 additional roles have been attributed to $\mathrm{PRL}$, including salt and water homeostasis, cellular growth, and proliferation (8). PRL influences the hypothalamo-pituitary-gonadal axis, inhibiting the secretion of pulsatile gonadotropin release hormone from the hypothalamus and modifying the activity of some steroidogenic enzymes (8). An excess or depletion of PRL secretion is associated with infertility and menstrual irregularity or even complete amenorrhea (9). In men, it causes increased testosterone and sperm production. Moreover, an excess of PRL can provoke galactorrhea (inappropriate milk production) in women and gynecomastia (breast development) in men (9).

$\mathrm{PRL}$ release is regulated by different factors including dopamine, thyrotropin releasing hormone, and nitric oxide (NO) (10). In the adenohypophysis, gonadotrophs and folliculostellate cells express neuronal nitric oxide synthase (nNOS) (11). Although NOS is not present in lactotrophs, these cells contain soluble guanylate cyclase, which leads to an increase in the rate of cGMP synthesis and a decrease in PRL release when stimulated by NO (10). However, in vitro cultures containing isolated lactotrophs could express NOS (a type of prolactinoma is nNOS positive), suggesting that autocrine modulation may occur in these conditions (11).

Cell lines releasing PRL have been widely used to study the molecular mechanisms underlying the modulation of hormone secretion, including hypothalamic factors, steroids, and thyrotropin releasing hormone (12). The aim of this study was to evaluate the effect of methylmercury on prolactin release and the role of the nitrergic system, using an experimental model of the rat mammosomatotroph cell line, GH3B6 prolactin secretory cells.

\section{Material and Methods}

\section{Chemicals}

Fetal bovine serum and horse serum were obtained from Gibco (UK). HAM-F12 medium, phosphate buffered saline (PBS), streptomycin, penicillin, gentamicin, methylmercury chloride ( $\mathrm{MeHgCl}, 99.8 \%), \mathrm{N}$-nitro-L-arginine (L-NARG), 3-[4,5-dimethylthiazol-2-yl]-2,5-diphenyl-tetrazolium bromide (MTT), and all reagents for radioimmunoassays were purchased from Sigma-Aldrich (USA).

\section{Cell culture}

The rat GH3B6 pituitary adenoma cell line was obtained from the American Type Culture Collection (ATCC; USA) and grown at $37^{\circ} \mathrm{C}$ under $5 \% \mathrm{CO}_{2}$ in HAM-F12 medium supplemented with $15 \%$ horse serum, $2.5 \%$ fetal bovine serum, $40 \mathrm{U} / \mathrm{mL}$ penicillin, $40 \mu \mathrm{g} / \mathrm{mL}$ streptomycin, and $1 \mu \mathrm{g} / \mathrm{mL}$ gentamicin. Approximately $2.5 \times 10^{5}$ cells were plated in $22 \mathrm{~mm}$ plastic Petri dishes and kept at $37^{\circ} \mathrm{C}$ under $5 \% \mathrm{CO}_{2}$ for $72 \mathrm{~h}$ before $\mathrm{MeHg}$ exposure.

\section{Methylmercury and N-nitro-L-arginine exposure}

Methylmercury chloride was diluted directly with serum-free culture medium. The GH3B6 cell line was incubated with $0-100 \mu \mathrm{M}$ of $\mathrm{MeHg}$ for 2 or $6 \mathrm{~h}$ at $37^{\circ} \mathrm{C}$ under $5 \% \mathrm{CO}_{2}$. Where required, co-treatment with $3 \mathrm{mM}$ L-NARG, a classic NOS inhibitor, was carried out for the same incubation times. This concentration was previously used for a similar purpose in cultured cells (13). Finally, cells and conditioned medium were collected for cellular viability determination and prolactin assays, respectively.

\section{Cellular viability determination}

Cellular viability was evaluated by MTT assay as previously described (14). In this assay, the active mitochondria of viable cells reduce the colorless tetrazolium salt MTT, forming dark blue insoluble formazan crystals. Control and MeHg-treated cells were washed twice with PBS and incubated for $3 \mathrm{~h}$ with $50 \mu \mathrm{L}$ of MTT stock solution $(5 \mathrm{mg} / \mathrm{mL})$ in $500 \mu \mathrm{L}$ of PBS. After incubation, $50 \mu \mathrm{L}$ of 2-propanol was added. Formation of formazan was detected at $570 \mathrm{~nm}$ and cellular viability was expressed as the percentage of reduced MTT compared with control values.

\section{Assay of prolactin release}

The prolactin concentration was determined in conditioned medium by double-antibody radioimmunoassay. The rat Prolactin RIA Kit was obtained from the National Hormone and Pituitary Program, National Institute of Diabetes and Digestive and Kidney Diseases, USA.

\section{Statistical analysis}

Statistical tests were performed with the INSTAT software (GraphPad, USA). A one-way analysis of variance (ANOVA), followed by Tukey's post hoc test when appropriate, was used to compare average values between groups. $\mathrm{P}<0.05$ was considered to be statistically significant.

\section{Results}

\section{Effect of methylmercury on cellular viability}

Exposure to methylmercury produced a significant decrease in cellular viability in a time-dependent manner at concentrations above $10 \mu \mathrm{M}$ (Supplementary Figure S1). When $100 \mu \mathrm{M} \mathrm{MeHg}$ was used, incubation for $6 \mathrm{~h}$ proved to be significantly more toxic than incubation for $2 \mathrm{~h}$ (viable cells reduced by approximately $50 \%$ and $30 \%$, respectively, compared with the control group; $\mathrm{P}<0.001$ ). The concentration-response curves were fitted to sigmoid curves designed to calculate $\mathrm{LC}_{50}$ values, which were 166.42 $\mu \mathrm{M}\left(\mathrm{R}^{2}=0.983\right)$ and $92.64 \mu \mathrm{M}\left(\mathrm{R}^{2}=0.968\right)$ for $2 \mathrm{~h}$ and $6 \mathrm{~h}$ of incubation, respectively. Based on these data, 1, 10, and $100 \mu \mathrm{M} \mathrm{MeHg}$ were selected for $2 \mathrm{~h}$ and 1 and $10 \mu \mathrm{M}$ for $6 \mathrm{~h}$ incubation to result in $>70 \%$ cell viability. 

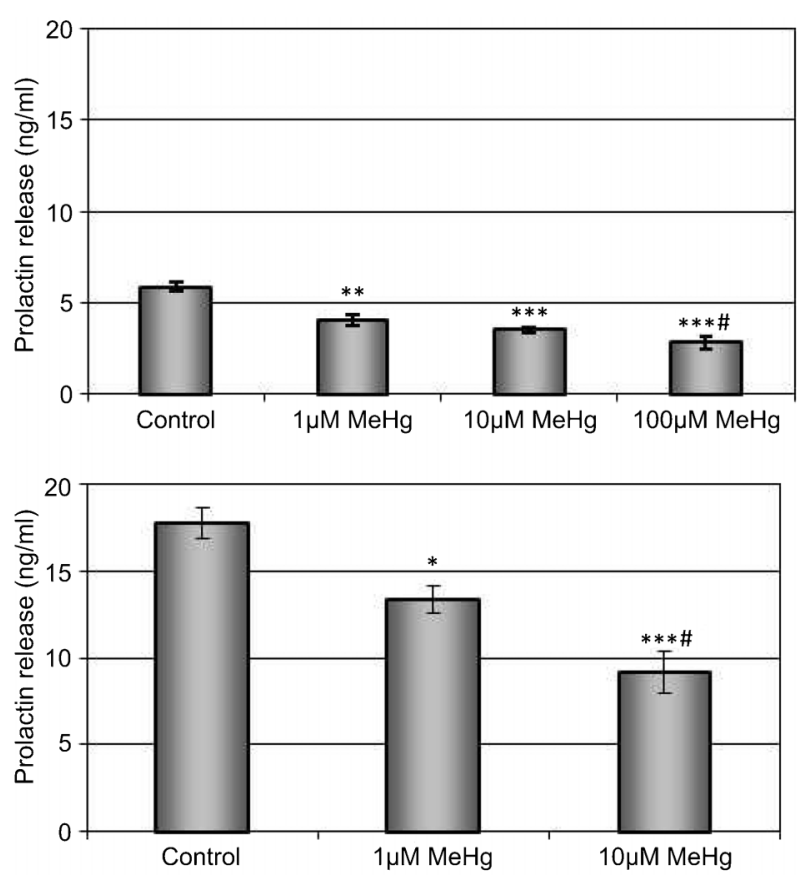

Figure 1. Prolactin release by the rat pituitary cell line GH3B6 exposed to different methylmercury ( $\mathrm{MeHg}$ ) concentrations for $2 \mathrm{~h}$ (top panel) or $6 \mathrm{~h}$ (bottom panel). Data are reported as means $\pm \mathrm{SE}(\mathrm{n}=6)$. ${ }^{*} \mathrm{P}<0.05,{ }^{* *} \mathrm{P}<0.01$, and ${ }^{* *} \mathrm{P}<0.001$ vs control; ${ }^{\#} \mathrm{P}<0.05$ vs the $1-\mu \mathrm{M}$ group (ANOVA with Tukey's test).

\section{Effect of methylmercury on prolactin release}

All $\mathrm{MeHg}$ concentrations significantly decreased prolactin release from $\mathrm{GH} 3 \mathrm{~B} 6$ cells (Figure 1). Incubation for $2 \mathrm{~h}$ resulted in lower levels of prolactin release than $6 \mathrm{~h}$ of incubation. $\mathrm{MeHg}$ inhibition of prolactin release was evident even at the lowest concentration $(1 \mu \mathrm{M}$; $\mathrm{P}<0.001)$. After $6 \mathrm{~h}$ of $\mathrm{MeHg}$ exposure, a significant difference $(\mathrm{P}<0.05)$ was detected between the 1- and 10$\mu \mathrm{M}$ MeHg-treated groups (Figure 1, bottom panel).

\section{Effect of L-NARG on the inhibition of prolactin release by methylmercury}

There were no differences in cellular viability and prolactin release, compared with the control groups, when GH3B6 cells were incubated with $3 \mathrm{mM} \mathrm{L-NARG} \mathrm{(Figures}$ 2 and 3). Co-incubation of MeHg and L-NARG completely prevented the decrease of prolactin release seen with 1 and $10 \mu \mathrm{M} \mathrm{MeHg}$ (Figures 2 and 3, top panels). However, L-NARG did not show any protective effect against the decreased release of prolactin when cells were exposed to $100 \mu \mathrm{M} \mathrm{MeHg}$ for $2 \mathrm{~h}$ (perhaps because of the significant reduction in cellular viability in those treatment groups). There was no significant difference in cellular viability between the other groups (Figures 2 and 3 , bottom panels).

\section{Discussion}

This work demonstrates, for the first time, using an in vitro approach, that $\mathrm{MeHg}$ exposure can significantly decrease prolactin release in cells of pituitary origin. The use of a cell line of neoplastic origin is the usual first step in toxicological studies. Specifically, in vitro models have traditionally been used for the analysis of mercury toxicity, especially to highlight cellular mechanisms in the brain $(1,2)$. In this study, MeHg exposure was limited to 2 or $6 \mathrm{~h}$ to study relatively rapid effects on prolactin release and to avoid excessive cell death.

$\mathrm{MeHg}$ exposure of cells of a mammosomatotroph origin showed a relevant cytotoxic effect only when the highest concentration was used $(100 \mu \mathrm{M})$. The $\mathrm{LC}_{50}$ values found in this study for MeHg toxicity in GH3B6 cells were higher than described elsewhere for astrocytes, neurons, and other cell lines with a central nervous system origin (2). This difference is probably due to longer $\mathrm{MeHg}$ incubations in the previous studies (24 h or more). In addition, the $\mathrm{LC}_{50}$ values in this study were higher than those reported in a previous study performed in cerebellar granule and retinal cell cultures with the same times of exposure, indicating cells of pituitary origin may have a higher resistance to $\mathrm{MeHg}$.

Interestingly, in vivo studies $(3,15)$ demonstrated that the pituitary gland (and especially the anterior pituitary) is one of the organs in which mercury accumulates. For example, high concentrations of mercury in the pituitary gland have been reported in monkeys following long-term subclinical $\mathrm{MeHg}$ exposure and in humans exposed to mercury vapor. Despite this distribution, the pituitary gland is not very sensitive to the effects of mercury toxicity when compared with the cerebellum or cortex. Thus, the higher resistance of cells of pituitary origin found in this work could be due to a protective role exerted by PRL against mercury toxicity, especially if one considers that the thiol groups of PRL can be used as scavengers of this metal (15).

Despite this possible resistance to cellular death, prolactin release in GH3B6 cells was dramatically affected by the two MeHg concentrations used (Figure 1) and decreased in a concentration-dependent manner. Exposure of the cells to $1 \mu \mathrm{M} \mathrm{MeHg}$ for $2 \mathrm{~h}$ was sufficient to generate a significant inhibition of prolactin production (reduction of $\sim 33 \%$ when compared with control cells). It is unlikely that extensive apoptosis produced the prolactin decrease observed in this work because Toimela et al. (16) demonstrated no caspase-3 activity in cell lines of CNS origin incubated for $6 \mathrm{~h}$ with $10 \mu \mathrm{M}$ of $\mathrm{MeHg}$. Low $\mathrm{MeHg}$ concentrations are able to produce a detectable level of apoptosis, but only after periods of incubation of up to $12 \mathrm{~h}(16)$. There may be several phenomena related to the suppression of prolactin release in GH3B6 cells induced by $\mathrm{MeHg}$; however, in the present work, we showed for the first time that the nitrergic system represents an important mediator of prolactin release. 

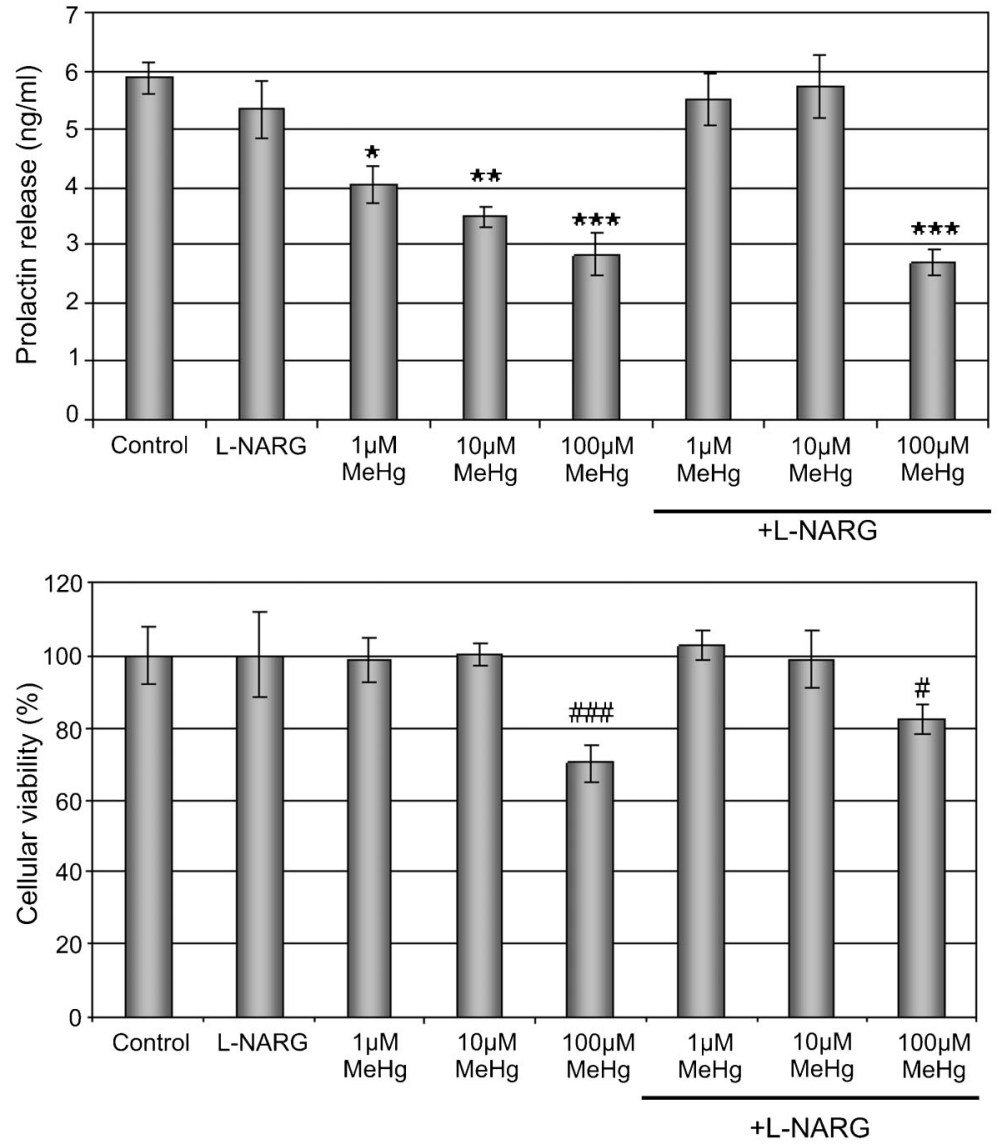

Figure 2. Prolactin release (top panel) and cellular viability (bottom panel) of the rat pituitary cell line GH3B6 exposed to different methylmercury $(\mathrm{MeHg})$ concentrations and/or $3 \mathrm{mM} \mathrm{N}$ nitro-L-arginine (L-NARG) for $2 \mathrm{~h}$. Data are reported as means \pm SE $(n=6)$. ${ }^{*} P<0.05$, ${ }^{* *} P<0.01$, and ${ }^{* * *} P<0.001$ vs control and groups incubated with L-NARG and L-NARG + MeHg (1 and $10 \mu \mathrm{M}$ ); ${ }^{\#} \mathrm{P}<0.05$ and ${ }^{\# \# \# \mathrm{P}<0.001 \text { vs all }}$ groups except those incubated with $100 \mu \mathrm{M}$ $\mathrm{MeHg}$ and L-NARG + $100 \mu \mathrm{M} \mathrm{MeHg}$ (ANOVA with Tukey's test).
Concentrations of $2.5-10 \mu \mathrm{M} \mathrm{MeHg}$ in the brain (estimated from human blood and hair mercury levels) have been associated with delayed psychomotor development in children and adults with minimal signs of $\mathrm{MeHg}$ poisoning $(1,17,18)$. Our results suggest that exposure to similar levels may lead to a decrease in prolactin release from the pituitary gland with consequences for the brain, pointing to the necessity of reviewing the tolerance values (30 $\mu \mathrm{g} / \mathrm{L}=30 \mathrm{ppb}$ or $0.03 \mathrm{ppm}$ ) published in 1990 by the World Health Organization. Our data contribute to the growing discussions about the safety limits of mercury exposure based on findings that long-term intake of relatively low levels of mercury induced sub-clinical neurobehavioral abnormalities $(1,2,18)$. These early effects may be due to the special sensitivity of the brain and other organs to $\mathrm{MeHg}$ toxicity, as described before $(1,2)$ and supported by our data.

The role of prolactin as a potential bioindicator of neurotoxicity in human populations at risk is currently being discussed $(7,18)$. Some studies found relationships between levels of urinary mercury (from both occupational and dietary exposure) and serum prolactin (18). However, the behavior of these relationships was not always the same, perhaps because of a different influence for each mercury compound (18). Therefore, it is essential to identify the factors controlling prolactin secretion.

Thus, in this work, one of the major cellular mechanisms of $\mathrm{MeHg}$ toxicity (oxidative stress produced by free radical generation) was studied to analyze its influence on prolactin release in cells of pituitary origin. $\mathrm{MeHg}$ is able to increase the generation of free radicals (highly reactive molecules with only a single electron in the highest electronic energy level) in many tissues (16). Actually, $\mathrm{MeHg}$ leads to activation of NOS (a key enzyme that synthesizes nitric oxide, a reactive oxygen species), leading to an increase in production of free radicals (2). Some studies have already demonstrated the protective effect exerted by antioxidants, such as vitamin $\mathrm{C}$ or melatonin (19), against mercury toxicity. Interestingly, inhibition of NOS by L-NARG completely prevented the decrease in prolactin release provoked by $\mathrm{MeHg}$, including when a higher concentration and a longer time of exposure were used (Figure 3, top panel). This strong relationship supports the idea that the $\mathrm{MeHg}$ effect on prolactin production may be mediated via free radical production and, especially, via activation of the nitrergic system. However, additional studies are being conducted to clarify whether MeHg actually activates NOS enzymes 

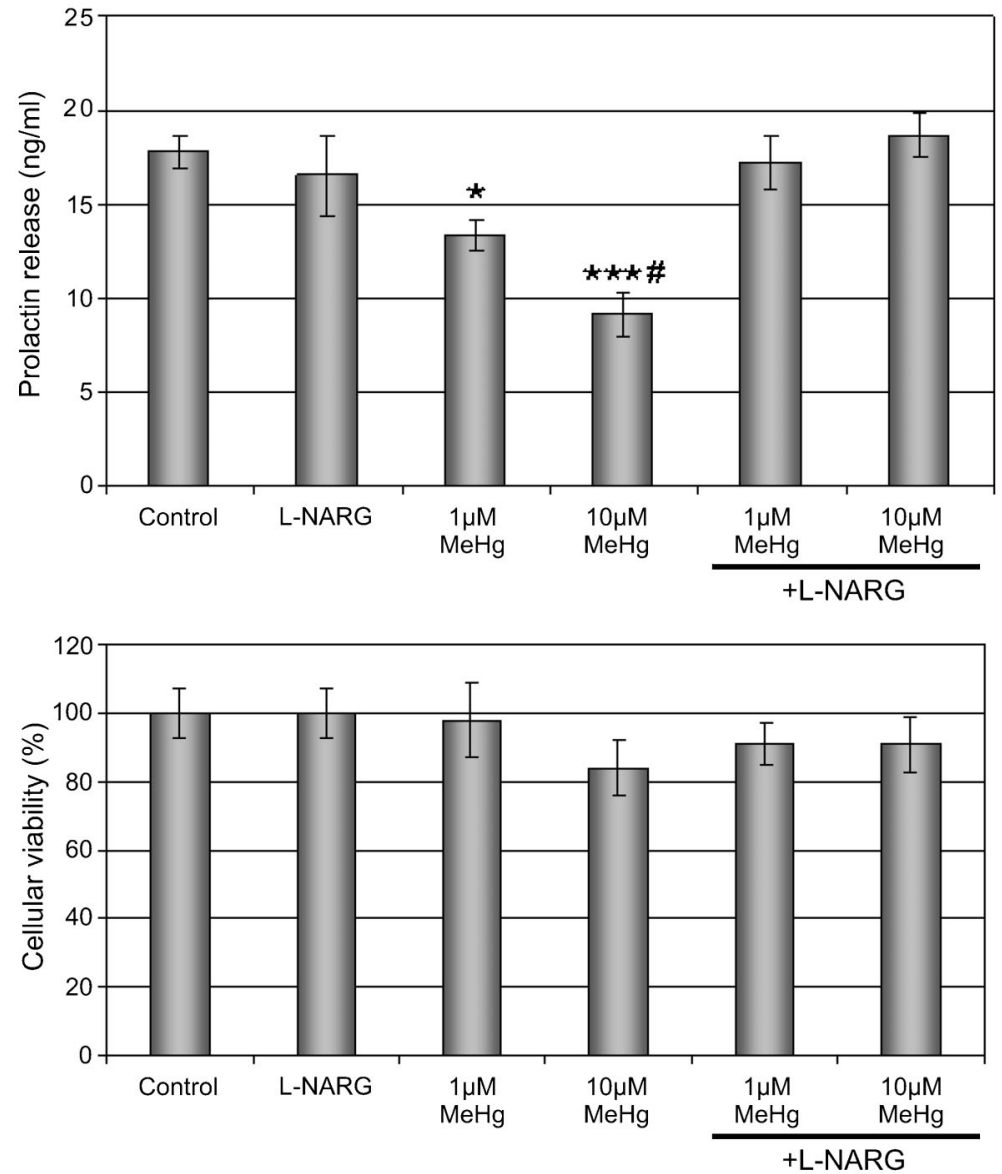

Figure 3. Prolactin release (top panel) and cellular viability (bottom panel) of the rat pituitary cell line GH3B6 exposed to different methylmercury $(\mathrm{MeHg})$ concentrations and/or $3 \mathrm{mM} \mathrm{N}$ nitro-L-arginine (L-NARG) for $6 \mathrm{~h}$. Data are reported as means \pm SE $(n=6)$. ${ }^{*} P<0.05$ and ${ }_{* * *} P<0.001$ vs control and groups incubated with L-NARG and $\mathrm{MeHg}+\mathrm{L}-\mathrm{NARG}$; ${ }^{\mathrm{P}}<0.05$ vs 1 $\mu \mathrm{M}$ group (ANOVA with Tukey's test). in GH3B6 cells, to eliminate the possibility that an intrinsic NOS activity, not affected by $\mathrm{MeHg}$, may participate in the MeHg-induced inhibition of PRL release.

In this study, we observed that treatment of $\mathrm{GH} 3 \mathrm{~B} 6$ cells with L-NARG did not alter the basal prolactin release; similar results have been described by Chiodera et al. (20). The authors showed that treatment of humans with L-NAME, an inhibitor of NOS, does not affect basal release of prolactin, but may cause an increase in prolactin release induced by vasoactive intestinal peptide (VIP). Thus, we believe that basal NOS activity does not interfere significantly with basal prolactin release, but the activation of this enzyme in GH3B6 cells induced by $\mathrm{MeHg}$ is an important inhibitory modulator of prolactin release. These effects may prove to be useful tools for elucidating the mechanisms by which prolactin release can be controlled.

The maintenance of prolactin secretion levels after exposure to $\mathrm{MeHg}$, due to inhibition of NOS, occurred without an acute neurotoxic effect since no significant difference was detected in cellular viability for groups incubated with 1 or $10 \mu \mathrm{M} \mathrm{MeHg}$ (Figures 2 and 3, bottom panel). Thus, the decrease in prolactin production appears to be an early effect of $\mathrm{MeHg}$ in cells of pituitary origin. Taking into account the versatility of $\mathrm{MeHg}$, other mechanisms of mercury toxicity, such as microtubule disruption, may also be participating simultaneously, because disassembly of tubulin microtubules could affect vesicle transport of prolactin. However, preliminary results of studies carried out with the same low doses and short exposure times used in this work indicated that microtubule modification would be minimal in these conditions (data not shown), suggesting that the nitrergic system is the major system responsible for the decrease of prolactin release because of $\mathrm{MeHg}$ exposure.

\section{Supplementary material}

Click here to view [pdf]

\section{Acknowledgments}

This research was supported in part by CNPq, PROCAD/CAPES, FAPESPA/PRONEX, and the FINEP research grant "Rede Instituto Brasileiro de Neurociência 
(IBN-Net)" \#01.06.0842-00. L.E. Nasciutti, M.E. Crespo-López, J. Antunes-Rodrigues, and J.L.M. do Nascimento are CNPq research fellows. The authors also

\section{References}

1. Pinheiro MC, Crespo-Lopez ME, Vieira JL, Oikawa T, Guimaraes GA, Araujo CC, et al. Mercury pollution and childhood in Amazon riverside villages. Environ Int 2007; 33: 56-61, doi: 10.1016/j.envint.2006.06.024.

2. Crespo-Lopez ME, Lima de SA, Herculano AM, Rodriguez BR, Martins do Nascimento JL. Methylmercury genotoxicity: a novel effect in human cell lines of the central nervous system. Environ Int 2007; 33: 141-146, doi: 10.1016/ j.envint.2006.08.005.

3. Oliveira FR, Ferreira JR, dos Santos CM, Macedo LE, de Oliveira RB, Rodrigues JA, et al. Estradiol reduces cumulative mercury and associated disturbances in the hypothalamus-pituitary axis of ovariectomized rats. Ecotoxicol Environ Saf 2006; 63: 488-493, doi: 10.1016/ j.ecoenv.2004.12.024.

4. Falnoga I, Tusek-Znidaric M, Horvat M, Stegnar P. Mercury, selenium, and cadmium in human autopsy samples from Idrija residents and mercury mine workers. Environ Res 2000; 84: 211-218, doi: 10.1006/enrs.2000.4116.

5. Amar AP, Weiss MH. Pituitary anatomy and physiology. Neurosurg Clin N Am 2003; 14: 11-23, v, doi: 10.1016/ S1042-3680(02)00017-7.

6. Silva-Pereira LC, da Rocha CA, Cunha LR, da Costa ET, Guimaraes AP, Pontes TB, et al. Protective effect of prolactin against methylmercury-induced mutagenicity and cytotoxicity on human lymphocytes. Int J Environ Res Public Health 2014; 11: 9822-9834, doi: 10.3390/ijerph110909822.

7. Alessio L, Lucchini R. Prolactin changes as a consequence of chemical exposure. Environ Health Perspect 2006; 114: A573-A574, doi: 10.1289/ehp.114-a573.

8. Freeman ME, Kanyicska B, Lerant A, Nagy G. Prolactin: structure, function, and regulation of secretion. Physiol Rev 2000; 80: 1523-1631.

9. Bachelot A, Binart N. Reproductive role of prolactin. Reproduction 2007; 133: 361-369, doi: 10.1530/REP-06-0299.

10. Kostic TS, Andric SA, Stojilkovic SS. Spontaneous and receptor-controlled soluble guanylyl cyclase activity in anterior pituitary cells. Mol Endocrinol 2001; 15: 10101022, doi: 10.1210/mend.15.6.0648.

11. Gonzalez-Hernandez T, Gonzalez MC. Gender differences and the effect of different endocrine situations on the NOS expression pattern in the anterior pituitary gland. thank the Pró-Reitoria de Pesquisa, Universidade Federal do Pará (PROPESP/UFPA) and the Fundação de Amparo a Pesquisa (FADESP) for support.
J Histochem Cytochem 2000; 48: 1639-1648, doi: 10.1177| 002215540004801207

12. de Carvalho DF, Silva KL, de Oliveria DA, Villa-Verde DM, Coelho HS, Silva LC, et al. Characterization and distribution of extracellular matrix components and receptors in GH3B6 prolactin cells. Biol Cell 2000; 92: 351-362, doi: 10.1016/ S0248-4900(00)01076-5.

13. Herculano AM, Crespo-Lopez ME, Lima SM, Picanco-Diniz $\mathrm{DL}$, do Nascimento JL. Methylmercury intoxication activates nitric oxide synthase in chick retinal cell culture. Braz J Med Biol Res 2006; 39: 415-418, doi: 10.1590/S0100-879X2006 000300013.

14. Mosmann T. Rapid colorimetric assay for cellular growth and survival: application to proliferation and cytotoxicity assays. J Immunol Methods 1983; 65: 55-63, doi: 10.1016/ 0022-1759(83)90303-4.

15. Lorenson MY, Patel T, Liu JW, Walker AM. Prolactin (PRL) is a zinc-binding protein. I. Zinc interactions with monomeric $\mathrm{PRL}$ and divalent cation protection of intragranular PRL cysteine thiols. Endocrinology 1996; 137: 809-816.

16. Toimela T, Tahti $H$. Mitochondrial viability and apoptosis induced by aluminum, mercuric mercury and methylmercury in cell lines of neural origin. Arch Toxicol 2004; 78: 565-574, doi: 10.1007/s00204-004-0575-y.

17. Burbacher TM, Rodier PM, Weiss B. Methylmercury developmental neurotoxicity: a comparison of effects in humans and animals. Neurotoxicol Teratol 1990; 12: 191202, doi: 10.1016/0892-0362(90)90091-P.

18. de Burbure C, Buchet JP, Leroyer A, Nisse C, Haguenoer $\mathrm{JM}$, Mutti A, et al. Renal and neurologic effects of cadmium, lead, mercury, and arsenic in children: evidence of early effects and multiple interactions at environmental exposure levels. Environ Health Perspect 2006; 114: 584-590, doi: 10.1289/ehp.8202.

19. Rao MV, Chinoy NJ, Suthar MB, Rajvanshi MI. Role of ascorbic acid on mercuric chloride-induced genotoxicity in human blood cultures. Toxicol In Vitro 2001; 15: 649-654, doi: 10.1016/S0887-2333(01)00081-9.

20. Chiodera P, Volpi R, Coiro V. Involvement of nitric oxide in vasoactive intestinal peptide-stimulated prolactin secretion in normal men. Metabolism 1998; 47: 897-899, doi: 10.1016/S0026-0495(98)90340-7. 